\title{
Community interactions dampen acidification effects in a coastal plankton system
}

\author{
D. Rossoll ${ }^{1}$, U. Sommer ${ }^{1}$, M. Winder ${ }^{1,2, *}$ \\ ${ }^{1}$ GEOMAR Helmholtz Centre for Ocean Research Kiel, Düsternbrooker Weg 20, 24105 Kiel, Germany \\ ${ }^{2}$ Department of Ecology, Environment and Plant Sciences, Stockholm University, 10691 Stockholm, Sweden
}

\begin{abstract}
Changing seawater chemistry towards reduced $\mathrm{pH}$ as a result of increasing atmospheric carbon dioxide $\left(\mathrm{CO}_{2}\right)$ is affecting oceanic organisms, particularly calcifying species. Responses of non-calcifying consumers are highly variable and mainly mediated through indirect ocean acidification effects induced by changing the biochemical content of their prey, as shown within single species and simple 2-trophic level systems. However, it can be expected that indirect $\mathrm{CO}_{2}$ impacts observed at the single species level are compensated at the ecosystem level by species richness and complex trophic interactions. A dampening of $\mathrm{CO}_{2}$-effects can be further expected for coastal communities adapted to strong natural fluctuations in $\mathrm{pCO}_{2}$, typical for productive coastal habitats. Here we show that a plankton community of the Kiel Fjord was tolerant to $\mathrm{CO}_{2}$ partial pressure $\left(\mathrm{pCO}_{2}\right)$ levels projected for the end of this century $(<1400 \mu \mathrm{atm})$, and only subtle differences were observed at the extremely high value of $4000 \mu \mathrm{atm}$. We found similar phytoand microzooplankton biomass and copepod abundance and egg production across all $\mathrm{CO}_{2}$ treatment levels. Stoichiometric phytoplankton food quality was minimally different at the highest $\mathrm{pCO}_{2}$ treatment, but was far from being potentially limiting for copepods. These results are in contrast to studies that include only a single species, which observe strong indirect $\mathrm{CO}_{2}$ effects for herbivores and suggest limitations of biological responses at the level of organism to community. Although this coastal plankton community was highly tolerant to high fluctuations in $\mathrm{pCO}_{2}$, increase in hypoxia and $\mathrm{CO}_{2}$ uptake by the ocean can aggravate acidification and may lead to $\mathrm{pH}$ changes outside the range presently experienced by coastal organisms.
\end{abstract}

KEY WORDS: Ocean acidification · Copepods · Phytoplankton · Mesocosm · Plankton community · Microzooplankton · Reproduction

Resale or republication not permitted without written consent of the publisher

\section{INTRODUCTION}

The reduction of ocean $\mathrm{pH}$ and shift in seawater carbon chemistry caused by increasing atmospheric carbon dioxide $\left(\mathrm{CO}_{2}\right)$, termed ocean acidification $(\mathrm{OA})$, is affecting a wide range of marine organisms (Fabry et al. 2008, Cooley et al. 2009). In particular, calcifying organisms respond sensitively to elevated $\mathrm{CO}_{2}$ levels (Engel et al. 2008, de Nooijer et al. 2009, Beaufort et al. 2011), whereas biological effects of OA on non-calcifying organisms are mixed and often highly species-specific (Doney et al. 2009, Whiteley 2011). Elevated levels of $\mathrm{CO}_{2}$ are expected to increase growth rates of photosynthetic organisms, a result that has been reported for some phytoplankton species (Kim et al. 2006, Fu et al. 2007) - although not consistently for a wide range of planktonic species. The responsiveness of phytoplankton to OA may depend on species-specific differences in the ability to use $\mathrm{CO}_{2}$ and bicarbonate $\left(\mathrm{HCO}_{3}\right)$ as a carbon source (Van de Waal et al. 2011). For zooplankton, direct physiological effects of $\mathrm{CO}_{2}$ on growth and reproduction are typically experienced only at extremely high levels of $\mathrm{CO}_{2}$ partial pressure $\left(\mathrm{pCO}_{2}\right)$ that exceed the projected increase for this century (Kurihara \& Ishimatsu 2008, Nielsen et al. 2010, Whiteley 2011). The strongest response to OA within non-calcifying primary consumers has been shown in 
simple 2 trophic level food chains through changes in nutritional prey quality that cause an imbalance between phytoplankton elemental and biochemical composition and consumer nutrient demand for somatic growth (Urabe et al. 2003, Rossoll et al. 2012). Increasing $\mathrm{CO}_{2}$ supply can stimulate carbon fixation by photosynthetic organisms and limit mineral nutrients of nitrogen $(\mathrm{N})$ and phosphorus $(\mathrm{P})$ and consequently reduce the nutrient content relative to carbon (Urabe et al. 2003, Bellerby et al. 2008, Engel et al. 2008). Similarly, as shown in a simple 2 -speciesfood chain with a diatom and a copepod species, both species were insensitive to $\mathrm{pCO}_{2}$ changes under current conditions, but at elevated $\mathrm{pCO}_{2}(750 \mu \mathrm{atm})$ polyunsaturated fatty acids were reduced in the diatoms and led to a decrease in copepod egg production (Rossoll et al. 2012). While these studies suggest strong indirect OA effects on zooplankton crustacean, it can be expected that differential sensitivity to $\mathrm{pCO}_{2}$ at the community and ecosystem level may compensate for indirect impacts observed at the single species level.

Experimental OA studies are often limited to simplified systems (but see Riebesell et al. 2008) including monocultures and simple 2 trophic interactions whereby a consumer species encounters a single prey species. These experimental setups exclude much of the structural complexity, ecophysiological variability, and genetic diversity encountered in natural communities (Paasche 2001, Lohbeck et al. 2012). Most experiments also fail to account for evolutionary adaptation that may mitigate adverse effects (Lohbeck et al. 2012). In situ, herbivores have the opportunity to choose between different phytoplankton food types that have different responsiveness to $\mathrm{pCO}_{2}$, which can mitigate effects imposed by monocultures (Urabe \& Waki 2009). In addition, most copepods considered traditionally 'herbivorous' are in fact omnivorous, which means that heterotrophic protists (often ciliates or heterotrophic dinoflagellates) can form a substantial part of their diet. Consumption of heterotrophic protists might compensate for biochemical deficiencies of algae, even if the heterotrophic protists form a relatively small portion of the available food spectrum (Klein Breteler et al. 2004, Ptacnik et al. 2004). Thus it can be expected that more complex communities might dampen $\mathrm{CO}_{2}$ effects, while the tolerance to $\mathrm{pCO}_{2}$ and $\mathrm{pH}$ might be lower for monocultures and simple 2-species interactions may amplify single-species effects.

Species richness and complex trophic interactions might provide a dampening of some effects caused by $\mathrm{CO}_{2}$, particularly in communities that experience strong natural fluctuations in $\mathrm{pCO}_{2}$. Coastal environments encounter often large amplitudes in $\mathrm{pCO}_{2}$ due to large fluxes of organic and inorganic carbon from river runoff, leading to wider $\mathrm{pH}$ variation in coastal systems compared to the open ocean (Hinga 2002). In addition, variation in $\mathrm{pCO}_{2}$ is more severe in estuarine brackish systems due to lower alkalinity and hence reduced buffer capacity (Melzner et al. 2013). Strong diel and seasonal shifts in the balance of photosynthesis and respiration can also lead to short term and seasonal $\mathrm{pCO}_{2}$ fluctuations that far exceed the atmospheric signal predicted for the next $100 \mathrm{yr}$ (IPCC 2007). Adaptations to a wide $\mathrm{pCO}_{2}$ range is particularly relevant for coastal plankton in nutrient rich areas, where respiration in deep layers and subsequent upwelling of $\mathrm{CO}_{2}$ enriched water result in acidification of surface waters (Feely et al. 2008). High $\mathrm{CO}_{2}$ fluctuations are characteristic for the western Baltic Sea, where seasonal monthly mean values of $\mathrm{pCO}_{2}$ range from 500 $\mu \mathrm{atm}$ (March) to $2500 \mu \mathrm{atm}$ (September) and short term variability might even span the range from 300 to 4500 patm (Melzner et al. 2013). In comparison, atmospheric $\mathrm{pCO}_{2}$ is expected to rise from current $390 \mu$ atm to values of 700 to $1000 \mu \mathrm{atm}$, and $\mathrm{pH}_{\text {NIST }}$ is expected to decrease from the present $~ 8.07$ to 7.73 by the end of this century (IPCC 2007, Cao \& Caldeira 2008, Gosling et al. 2011).

Here we test the tolerance of an experimentally enclosed natural plankton community of the Baltic Sea to elevated $\mathrm{pCO}_{2}$ levels and show the development of 3 trophic levels grown at present $\mathrm{pCO}_{2}$ (380 $\mu \mathrm{atm})$, future levels by 2100 according to IPCC predictions $(840,1120$, and $1400 \mu \mathrm{tm})$ and at a high $\mathrm{pCO}_{2}$ level $(4000 \mu \mathrm{atm})$ that served as a proof of principle for $\mathrm{CO}_{2}$ responses. The former 3 levels are within the mean trend of seasonal variation within the western Baltic Sea, while the latter value has only been reached during a few measurements in late summer and early fall (Melzner et al. 2013). We hypothesized that (1) higher aggregate phytoplankton responses (e.g. total biomass) to acidification will be less pronounced than single species responses, (2) the copepod Acartia tonsa will respond less sensitively to OA compared to a 2 -species experiment that excluded community complexity (Rossoll et al. 2012), and (3) most of the observed effects will be driven by the differences between the 1400 and 4000 patm $\mathrm{pCO}_{2}$ treatment, while differences between the 380 and $1400 \mu \mathrm{atm}$ treatments will be minor. To test these hypotheses, bloom dynamics and elemental composition of primary producers were measured as well as development and reproduction of the planktonic copepod A. tonsa. 


\section{MATERIALS AND METHODS}

\section{Mesocosm setup and $\mathrm{CO}_{2}$ manipulation}

Baltic seawater from Kiel Fjord containing the natural summer (August 2009) phyto- and microzooplankton community was pumped into a 1500 l stock tank and subsequently distributed to 12 mesocosms of 3001 volume each, depth of $1 \mathrm{~m}$ and diameter of $1.5 \mathrm{~m}$. The mesocosms were set up in temperature-controlled culture rooms and kept at constant temperature of $18^{\circ} \mathrm{C}$ and salinity of 18.1 . Mesocosms were initially manipulated with $\mathrm{CO}_{2}$-enriched air with 5 different $\mathrm{pCO}_{2}$ levels: $3 \times 380,1 \times 840,2 \times 1120,2 \times 1400$ and $2 \times 4000$ uatm. In the initial phase, mesocosm seawater was bubbled with corresponding $\mathrm{CO}_{2}$-enriched air for $48 \mathrm{~h}$ using wooden aqua stone-endings (Knudsen Aquaristik) to ensure maximum distribution. After the initial phase, direct $\mathrm{CO}_{2}$ supplied into the water was stopped and the headspace of each mesocosm was aerated continuously over the whole experimental time with the targeted $\mathrm{CO}_{2}$ level. To avoid outgassing, the top of each mesocosm was closed with plexiglass and fixed with elastic clamps. The light supply was set to simulate an average August day with sunrise at 05:17 $\mathrm{h}$ and sunset at 18:43 $\mathrm{h}$ using 6 fluorescent tubes ( $5 \times$ JBL Solar Tropic, each $4000 \mathrm{~K}_{i} 1$ $\times$ JBL Solar Natur, $9000 \mathrm{~K}$ ); duration of sunrise/sunset was set to $2 \mathrm{~h} 39 \mathrm{~min}$. Total light energy per day was $20.575 \mathrm{~kW} \mathrm{~m}{ }^{-2}$, which corresponds to $\sim 4 \mathrm{~m}$ water depth on sunny days. Total incubation time for the experiment was $28 \mathrm{~d}$.

The natural plankton community was allowed to acclimatize to changing $\mathrm{CO}_{2}$ levels for $1 \mathrm{wk}$. On Day 8 a plankton bloom was initiated by additions of sodium dihydrogen phosphate $\left(\mathrm{NaH}_{2} \mathrm{PO}_{4}\right)$, sodium silicate $\left(\mathrm{Na}_{2} \mathrm{SiO}_{3}\right)$ and sodium nitrate $\left(\mathrm{NaNO}_{3}\right)$ to reach dissolved concentrations of $35 \mu \mathrm{mol} \mathrm{l}^{-1}$ inorganic nitrogen, $40 \mu \mathrm{mol} \mathrm{\textrm {l } ^ { - 1 }}$ silicate and $2.2 \mu \mathrm{mol} \mathrm{\textrm {l } ^ { - 1 }}$ phosphate. On Day 11 of the experiment, Acartia tonsa nauplii (Stage 2) from a stock culture were added to the mesocosms to reach a starting density of $\sim 40$ ind. $1^{-1}$. For this purpose, A. tonsa eggs from indoor cultures were incubated in 6 incubation buckets $\left(10 \mathrm{l}\right.$ ) with $\mathrm{CO}_{2}$ pre-treated (as per the above $\mathrm{CO}_{2}$ levels) and filtrated $(0.2 \mu \mathrm{m})$ seawater until hatching at $18^{\circ} \mathrm{C}$ and development to Stage 2 .

\section{Sampling and sample analysis}

Salinity, temperature, and pH (NIST scale) of the mesocosm water were monitored daily using a WTW 340i pH-analyzer connected to a SENTIX-81 electrode. Water samples were taken from each mesocosm 3 times per week using a silicone tube. Before sampling, each mesocosm was smoothly stirred with a Secchi disc to resuspend settled phytoplankton and protozoan cells. Samples of dissolved inorganic carbon (DIC) for measuring initial $\mathrm{pCO}_{2}$ were taken at the beginning of the experiment, filtered with $0.2 \mu \mathrm{m}$ pre-filters via syringe and stored in $2 \mathrm{ml}$ brown flasks at $4{ }^{\circ} \mathrm{C}$ until analysis (described in Rossoll et al. 2012).

Total alkalinity (TA) samples of $50 \mathrm{ml}$ volume were taken weekly and immediately poisoned with mercury chloride. TA was analyzed potentiometrically in duplicate with an open-cell titration technique according to Dickson et al. (2003) with an average precision between duplicate measurements of $\leq 4 \mu \mathrm{mol}$ $\mathrm{kg}^{-1}$. Seawater samples of 10 to $12 \mathrm{~g}$ filtered on $\mathrm{GF} / \mathrm{F}$ were exactly weighed (1416B MP8-1, Sartorius). Titration was conducted using an automatic titrator (Titrando 808, Metrohm); hydrochloric acid ( $\mathrm{HCl})$ with a concentration of $0.005 \mathrm{~N}$ served as titrand. Dissolved inorganic nutrients (nitrite/nitrate, ammonium, silicate and phosphate) were measured according to standard protocols (see Fig. 1 for measured nutrient concentrations over the duration of the experiment).

A volume of 150 to $200 \mathrm{ml}$ of sample water was filtered onto pre-combusted Whatman GF/F filters for particulate organic carbon (POC), nitrogen (PON), phosphoros (POP) and chlorophyll a (chl a) measurements, respectively. POC and PON were analyzed using an elemental analyser; POP was analyzed by the ammonium molybdate method (Grasshoff et al. 1983) and chl a using a spectrophotometer (Hitachi U-2900) with the absorption equation of Strickland \& Parsons (1968) after acetone extraction. Phytoplankton and protozoan samples of $250 \mathrm{ml}$ were fixed with Lugol's iodine for microscopic analysis according to Utermöhl's (1958) method. Mesozooplankton was sampled 2 times per week (Mondays and Fridays) using a plankton net (64 $\mu \mathrm{m}$ mesh size, $6 \mathrm{~cm}$ diameter), fixed with formalin, and identified to life stages.

\section{Copepod egg production experiment}

After 28 d of mesocosm incubation, adult Acartia tonsa females were isolated from each mesocosm and transferred into $500 \mathrm{ml}$ chambers filled with $\mathrm{CO}_{2}$-enriched seawater of the related mesocosms and under the same conditions as the mesocosm (e.g. closed chambers with no headspace). To sepa- 

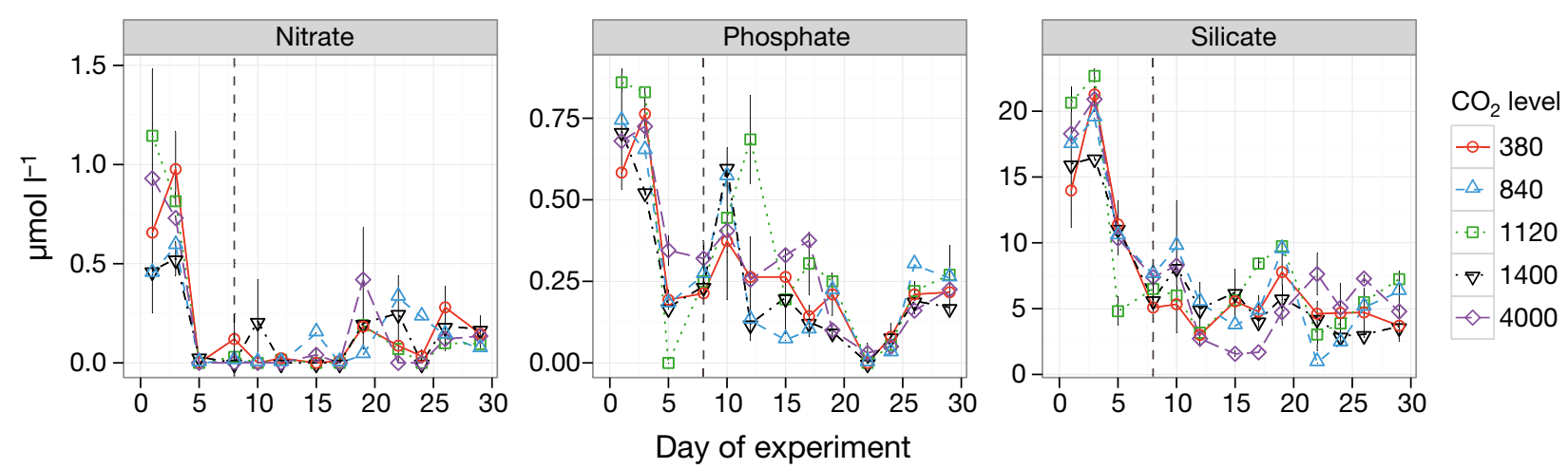

Fig. 1. Mean $( \pm \mathrm{SE})$ nutrient (nitrate, phosphate, silicate) concentration within $\mathrm{CO}_{2}$ treatment levels over the duration of the experiment. Dashed lines indicate the day of nutrient addition (Day 8)

rate the copepods from produced eggs, a mesh of $250 \mu \mathrm{m}$ separated the chambers. Egg chambers each with 5 females per treatment were set up as follows: $10 \times 380,9 \times 840,9 \times 1120,10 \times 1400$ and $10 \times 4000 \mu$ atm $\mathrm{pCO}_{2}$ with 3 to 5 replicate for each mesocosm. Living female copepods were separated from the egg chambers after $24 \mathrm{~h}$ incubation and all eggs and hatched nauplii were transferred into $20 \mathrm{ml}$ airtight hatching chambers for another incubation of $48 \mathrm{~h}$, followed by formalin preservation to avoid further development or disintegration in the aftermath. Nauplii, hatched and empty eggs of the hatching chambers were categorized and nauplii were further analyzed for developmental malfunctions.

Differences in plankton variables between treatments were tested using analysis of variance (ANOVA). A Tukey HSD post hoc test was used to assess differences among treatments.

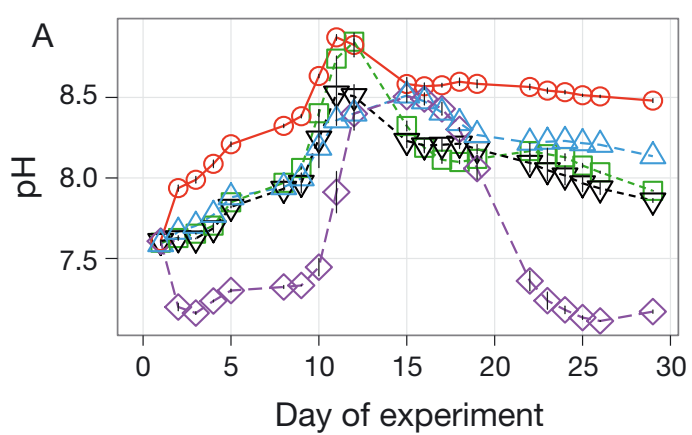

\section{RESULTS}

\section{Carbonate system}

Starting $\mathrm{pCO}_{2}$ concentration of the Baltic seawater used for mesocosm filling was 1600 patm with a mean $( \pm \mathrm{SD}) \mathrm{pH}_{\mathrm{NIST}}$ of $7.61 \pm 0.01$ and TA of $2023 \pm$ $10 \mu \mathrm{mol} \mathrm{kg}{ }^{-1}$ across all mesocosms (Fig. 2). After $2 \mathrm{~d}$ of $\mathrm{CO}_{2}$ adjustment, all mesocosms reached the $\mathrm{CO}_{2}$ target levels of 380, 840,1120, 1400 and $4000 \mu \mathrm{atm}$ as indicated by the difference in $\mathrm{pH}$. Measured $\mathrm{pH}$ values varied over the duration of the experiment and were strongly associated with phytoplankton bloom development (Figs. 2A \& 3A). Given that $\mathrm{pCO}_{2}$ was manipulated only at the beginning of the experiment and the $\mathrm{pH}$ was allowed to vary with plankton metabolism, the treatments were not discrete $\mathrm{pCO}_{2}$ manipulations. Nevertheless, $\mathrm{pH}$ differences were maintained within $\mathrm{CO}_{2}$ treatments, particularly

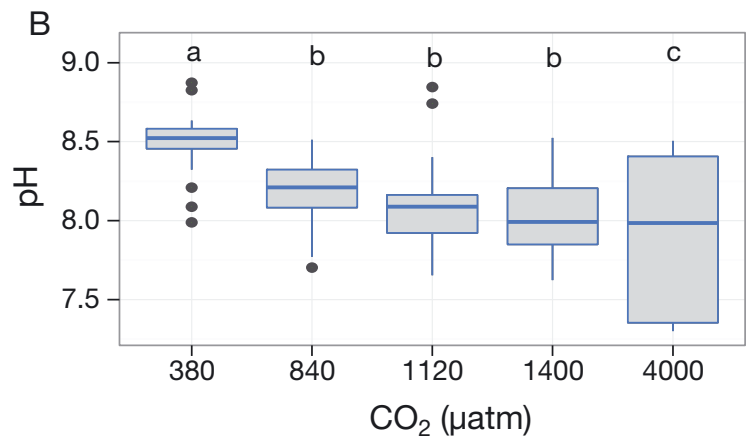

Fig. 2. Mean $( \pm \mathrm{SE}) \mathrm{pH}_{\mathrm{NIST}}$ values over the course of the experiment across $\mathrm{CO}_{2}$ treatment levels. (A) Temporal development of $\mathrm{pH}$. (B) Daily measured $\mathrm{pH}$ over the duration of the experiment. Bars: 50th percentile; boxes: 25th and 75th percentiles; whiskers: 10th and 90th percentiles; black points: outliers. Letters above bars $(a, b, c)$ represent significant differences based on a Tukey HSD test 
between the low (380 $\mu$ atm), medium $(840,1120$, $1400 \mu \mathrm{atm})$ and high (4000 $\mu \mathrm{atm}) \mathrm{pCO}_{2}$ levels, suggesting reduced outgassing (Fig. 2B). TA was on average $2058 \pm 24 \mu \mathrm{mol} \mathrm{kg}{ }^{-1}$ in all treatments during the whole experiment (data not shown).

\section{Phytoplankton and seston elemental composition}

Following the addition of nutrients on Day 8, chl a concentration increased from $\sim 5 \mathrm{gg} \mathrm{l}^{-1}$ to $\sim 40 \mu \mathrm{g} \mathrm{l}^{-1}$ on Day 10 at the lowest $\mathrm{pCO}_{2}$ (380 and $840 \mu \mathrm{atm}$ ) and to $\sim 30 \mu \mathrm{g} \mathrm{l}^{-1}$ at intermediate $\mathrm{pCO}_{2}$ (1120 and $1140 \mu \mathrm{atm})$ treatment levels, whereas phytoplankton peak timing was delayed for $2 \mathrm{~d}$ at $\mathrm{pCO}_{2} 4000 \mu \mathrm{atm}$ and reached a peak concentration of $\sim 30 \mu \mathrm{g} \mathrm{l}^{-1}$ (Fig. 3A). C:N ratios were comparable between the 380 and 1400 patm treatments over the duration of the experiment. During the bloom to postbloom period, C:N ratios increased significantly $(p=0.001)$ from an average of $\sim 7$ to 14 at the highest $\mathrm{CO}_{2}$ level
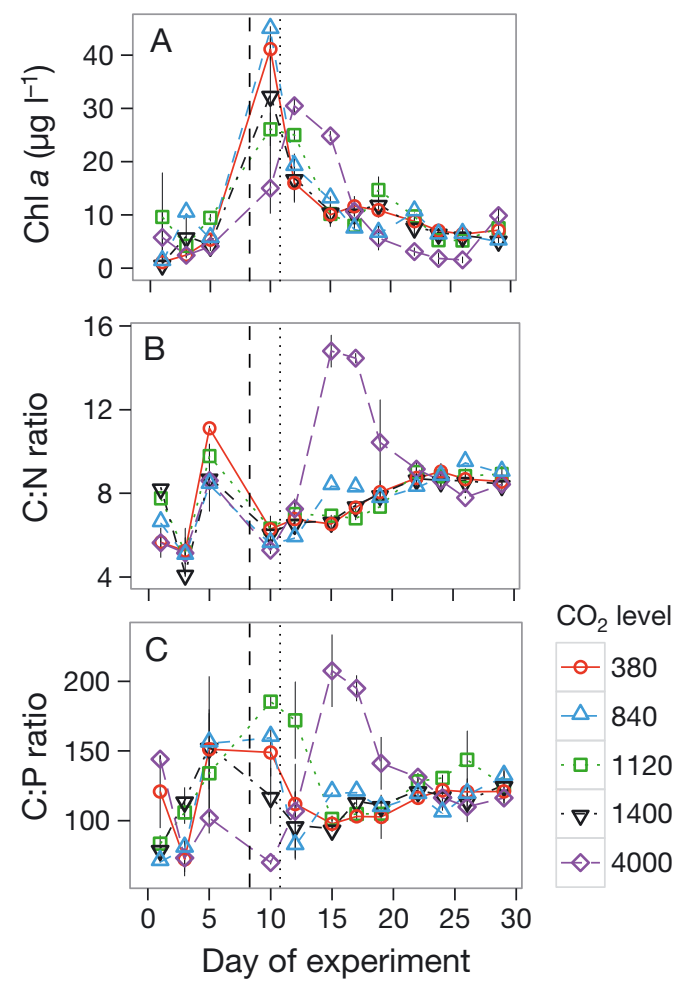

Fig. 3. Temporal development of mean $( \pm \mathrm{SE}) \mathrm{chl} a$ and elemental composition over the duration of the experiment at different $\mathrm{CO}_{2}$ treatment levels ( $\mu \mathrm{atm}$ ). (A) Chl a concentration, (B) particulate organic carbon to nitrogen molar ratio $(\mathrm{C}: \mathrm{N})$ and $(\mathrm{C})$ carbon to phosphate molar ratio (C:P). Dashed lines indicate the day of nutrient addition (Day 8), dotted lines the addition of copepod nauplii (Day 11)
(4000 $\mu$ tam) (Fig. 3B). Conversely, C:P ratios were lowest at $\mathrm{CO}_{2}$ values of 380 and $840 \mu \mathrm{atm}$, and increased from $\sim 115$ to 125 at higher $\mathrm{CO}_{2}$ levels during the bloom to postbloom period (Fig. 3C). However, this difference was not significant.

Phytoplankton biomass followed the same pattern as chl a concentration and increased after nutrient addition. The phytoplankton bloom was short-lived and the temporal development matched closely between mesocosms within the $\mathrm{pCO}_{2}$ treatment levels of 380 to 1400 atm (Fig. 4A). At 4000 uatm phytoplankton biomass showed a delayed response to nutrient addition with a lag time of about $5 \mathrm{~d}$ and a comparable peak magnitude to lower $\mathrm{pCO}_{2}$ treatments. Phytoplankton community composition and peak magnitude was similar between treatments and was dominated by diatoms, mainly Skeletonema sp. and Leptocylindrus sp., and to a lesser extent by dinoflagellates (Figs. 5 \& 6). Microzooplankton biomass was dominated by ciliates (scuticociliates, strobilidiid ciliates, Euplotes sp.) and increased after the
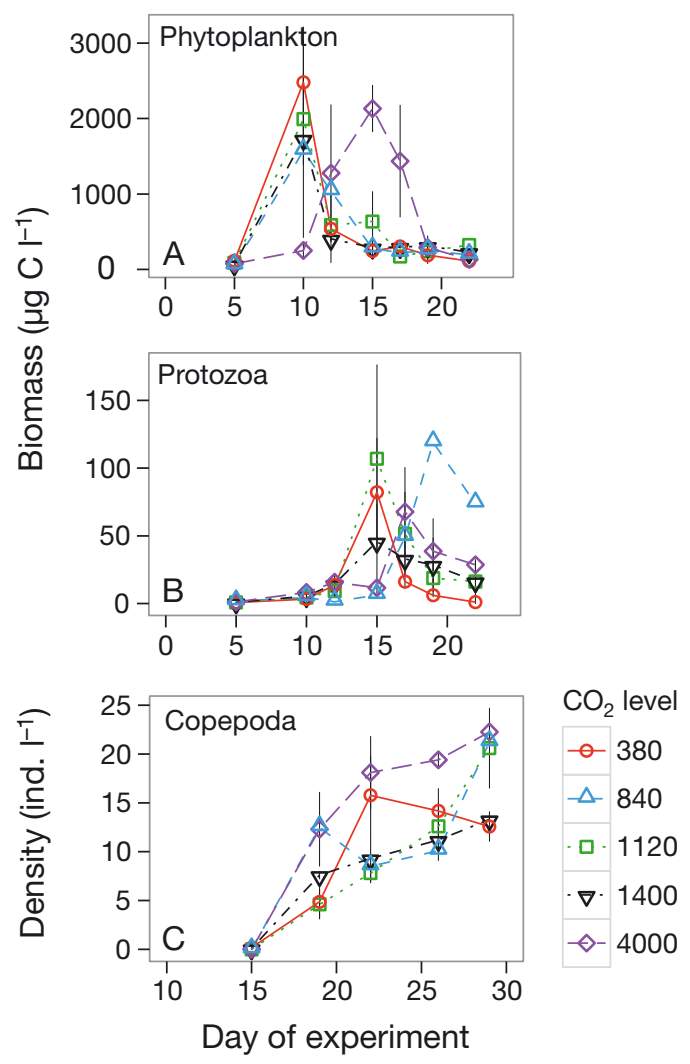

Fig. 4. Mean ( \pm SE) (A) phytoplankton biomass, (B) protozoa biomass and (C) copepod Acartia tonsa density over the course of the experiment among $\mathrm{CO}_{2}$ treatment levels ( $\mu$ atm). Copepod densities were counted after nauplii addition on Day 11 


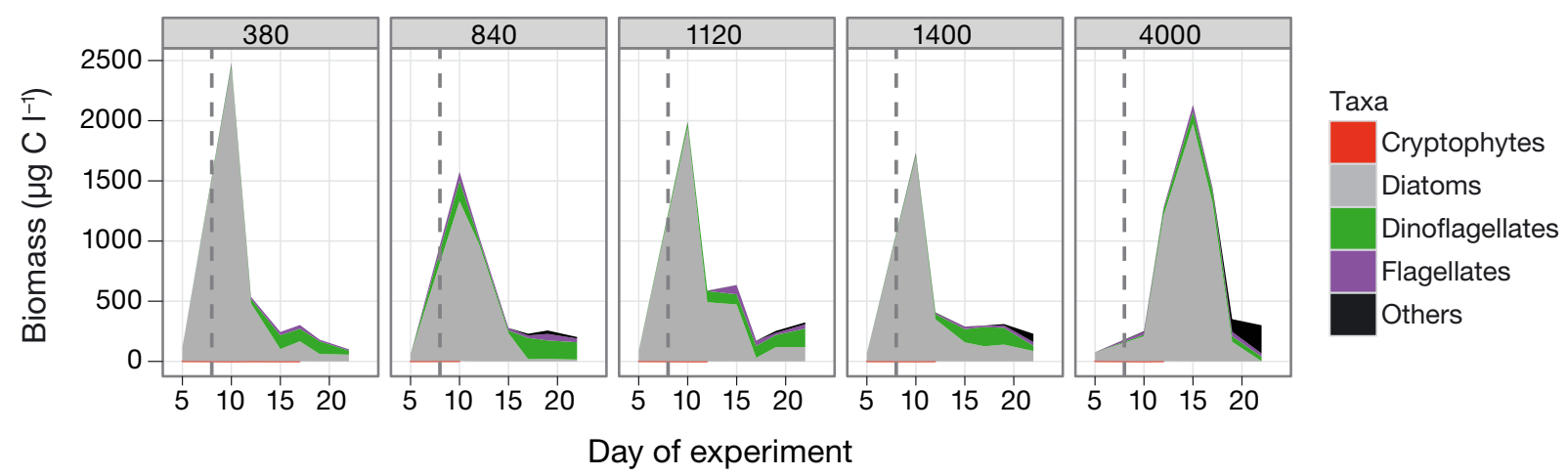

Fig. 5. Phytoplankton development of major taxonomic groups within $\mathrm{CO}_{2}$ treatment levels ( $\mu$ atm). Dashed lines indicate the day of nutrient addition (Day 8)

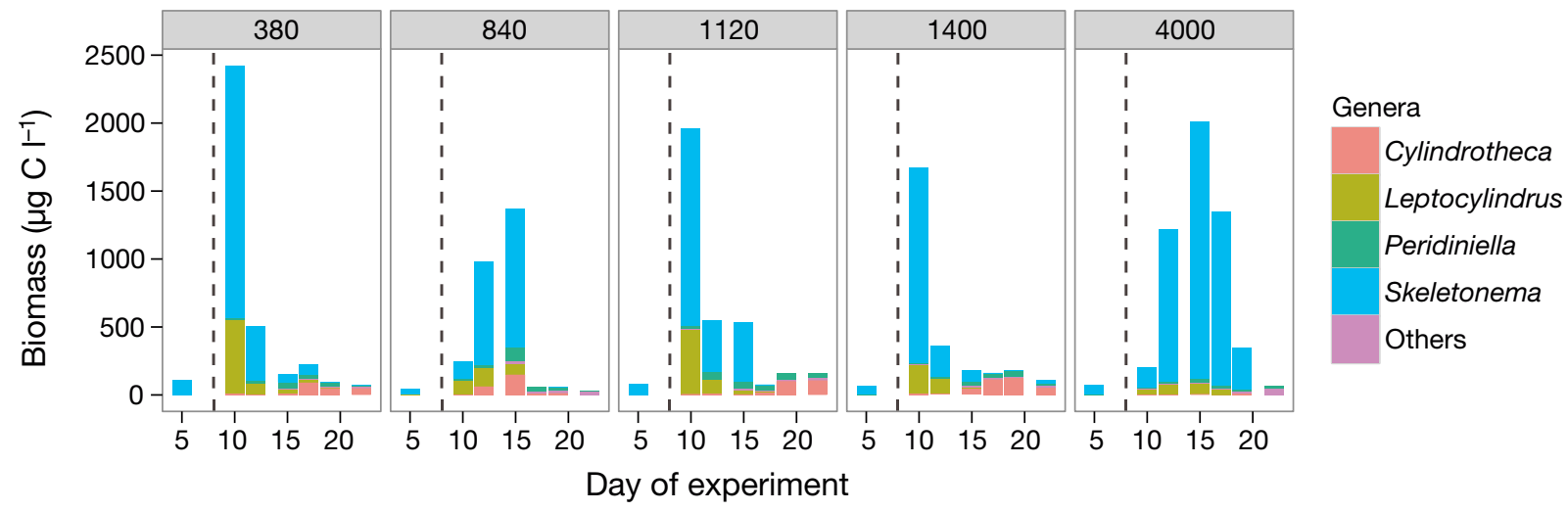

Fig. 6. Mean biomass of phytoplankton genera across different $\mathrm{pCO}_{2}$ treatment levels $(\mu \mathrm{atm})$. Dashed lines indicate the day of nutrient addition (Day 8)

phytoplankton bloom. The treatments of 380 to 1400 utam reached similar microzooplankton biomass concentrations on experimental Day 15 (Fig. 4B). Similar to phytoplankton, protozoa peak biomass was delayed for $\sim 5 \mathrm{~d}$ at $4000 \mu \mathrm{atm}$. Average protozoan biomass during the whole experiment was comparable across the $\mathrm{CO}_{2}$ gradient $(\mathrm{p}>0.1)$.

Abundance of Acartia tonsa increased after nauplii addition in all $\mathrm{CO}_{2}$ treatment levels (Fig. 4C). Average abundances over the copepod growth period were consistent between $\mathrm{pCO}_{2}$ treatments of 380 to 1400 patm ( 11 ind. $\left.\mathrm{l}^{-1}\right)$ and density was higher with $\sim 18$ ind. $\mathrm{l}^{-1}$ at $4000 \mu \mathrm{atm}$. The majority of individuals reached the adult Stage at Day 26 and development was similar between $\mathrm{CO}_{2}$ levels (Fig. 7A). Egg production of A. tonsa was lowest at 380 and $840 \mu \mathrm{atm}$ $\left(\sim 25 \pm 10\right.$ eggs female $\left.{ }^{-1} \mathrm{~d}^{-1}\right)$ and showed a tendency of increasing production at higher $\mathrm{pCO}_{2}$ with highest egg production of $52 \pm 19$ eggs female ${ }^{-1} \mathrm{~d}^{-1}$ at 4000 ratm (Fig. 7B), but this was not statistically significant. These relatively high egg production rates (for comparison see Holste \& Peck 2006) suggest that
A. tonsa was not limited by food availability after the bloom at the end of the experiment. Egg hatching success was on average $60 \pm 19 \%$ and did not vary across $\mathrm{pCO}_{2}$ treatments (data not shown).

\section{DISCUSSION}

Predicting marine community vulnerability to OA is challenging, as experimental setups often limit biological or ecological complexity and diversity when compared to natural systems (Thomsen et al. 2010). However, understanding OA effects at ecosystem level is important as complex communities could either dampen or aggravate $\mathrm{CO}_{2}$ effects experienced at the single species level. Moreover, in productive coastal habitats, such as the Eastern Pacific (Feely et al. 2008) and the Baltic Sea (Thomsen et al. 2010) that experience high natural $\mathrm{pCO}_{2}$ fluctuations, evolutionary adaptation may favor genotypes that are less $\mathrm{pH}$ sensitive compared to oceanic species (Melzner et al. 2013). Using a natural coastal plankton commu- 
A

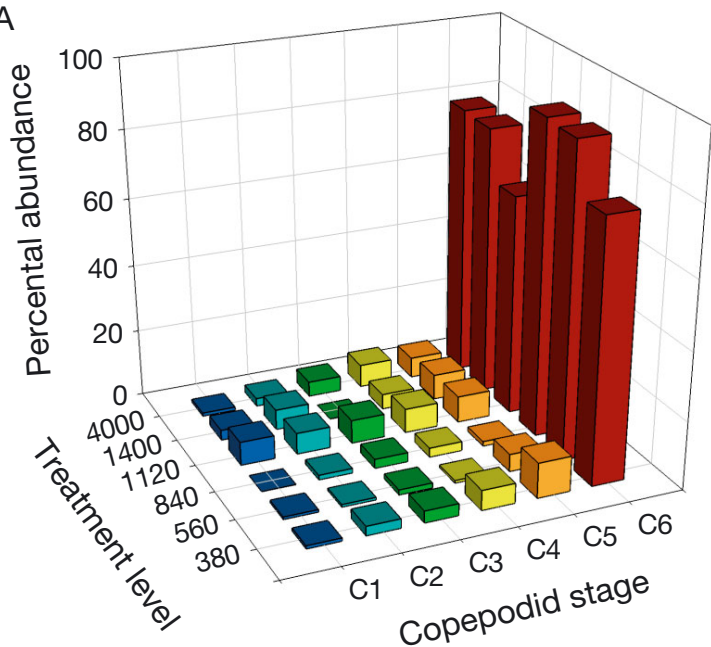

B

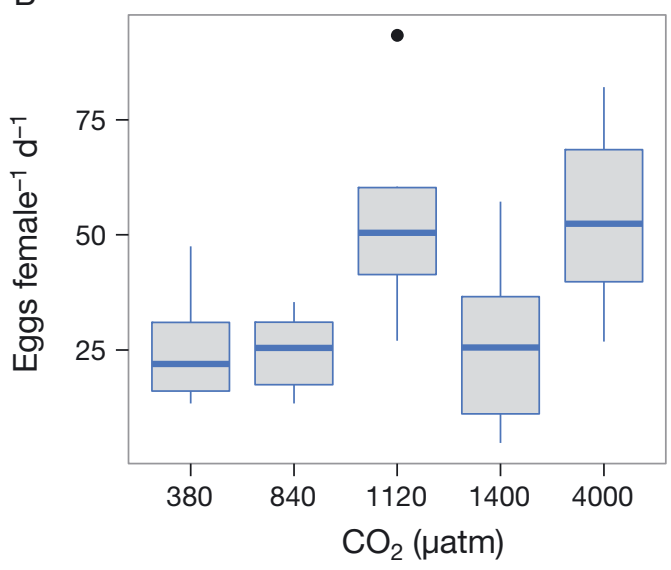

Fig. 7. Development and egg production of Acartia tonsa. (A) Age distribution on Day 26 of the experiment across $\mathrm{CO}_{2}$ treatment levels ( $\mu \mathrm{atm}$ ) and (B) copepod egg production at the end of the experiment (Day 28), for 8 to 10 egg chambers per $\mathrm{CO}_{2}$ level with 5 female copepods per chamber. Boxplot features as in Fig. 2B

nity from Kiel Fjord we observed only subtle changes (in plankton dynamics, reproduction and elemental composition) from initial $\mathrm{pCO}_{2}$ manipulations to high $\mathrm{CO}_{2}$ treatment levels. The resilience of the plankton community to OA can likely be explained by the naturally large seasonal and daily variance of $\mathrm{pH}$ and $\mathrm{CO}_{2}$ experienced by the community in this productive low-salinity region, suggesting that this community is adapted to strong $\mathrm{pCO}_{2}$ fluctuations.

Supporting our above conjecture, the $\mathrm{pCO}_{2}$ value measured in Kiel Fjord at the start of the experiment was $1600 \mu \mathrm{atm}$. The Western Baltic Sea (Kiel Bay) experiences large seasonal fluctuations in $\mathrm{pCO}_{2}$ ranging on average from about $500 \mu$ atm during winter to 2500 patm during summer, and seasonal $\mathrm{pH}$ changes of $\sim 8$ to 7.5 . High $\mathrm{pCO}_{2}$ fluctuations are a result of lower alkalinity and consequently lower buffering capacity of brackish water compared to seawater. In addition, nutrient enrichment strongly drive $\mathrm{pCO}_{2}$ to more extreme values by promoting plankton blooms that remove inorganic $\mathrm{C}$ from the water, and subsequent remineralization lowers the $\mathrm{pH}$ through the generation of $\mathrm{CO}_{2}$. Consequently, high natural $\mathrm{pCO}_{2}$ values - as observed at the beginning of this experiment-are not unusual for this coastal community. However, this also indicates that the lower $\mathrm{CO}_{2}$ treatments were in fact deacidification treatments compared to the natural environment.

Our assumption was that higher aggregate phytoplankton responses (e.g. total biomass) to acidification will be less pronounced than single species responses (hypothesis 1). In fact, neither the single species nor the total biomass parameter showed a significant response to $\mathrm{CO}_{2}$ enrichment. There was a tendency of reduced phytoplankton biomass at the highest $\mathrm{pCO}_{2}$ treatment, which is likely due to an immediate imposed stress to the community or increased grazing pressure. The delayed phytoplankton peak at 4000 patm suggests that the immediate injection of $\mathrm{CO}_{2}$ induced a temporary stress for phytoplankton growth; after a few days, however, growth returned to normal levels. Our findings are in accordance with other studies that found no significant changes in growth, taxonomic shifts, photosynthetic activity or total PON and POC of coastal phytoplankton communities within realistic future predicted OA scenarios (Berge et al. 2010, Nielsen et al. 2010). However, truly oceanic species and calcifying organisms might be sensitive to anthropogenic $\mathrm{CO}_{2}$ changes (Müller et al. 2010) as diel and seasonal $\mathrm{CO}_{2}$ variability are generally lower in oligotrophic oceans compared to high productive coastal sites. Calcifying organisms depend on the saturation state of calcium carbonate $\left(\mathrm{CaCO}_{3}\right)$, which decreases with increasing $\mathrm{CO}_{2}$ levels and resulting lower $\mathrm{pH}$ of seawater (Beaufort et al. 2011). In general, the current state of knowledge reveals either little change or enhanced primary productivity with elevated $\mathrm{CO}_{2}$ and sparse information about significant changes in dominant non-calcifying phytoplankton species. Comparable to phytoplankton, neither total microzooplankton biomass nor species composition was significantly influenced by the $\mathrm{CO}_{2}$ treatments. Direct $\mathrm{CO}_{2}$ effects 
on microzooplankton physiology are not to be expected (Nielsen et al. 2010), instead indirect OA effects through the variation in prey dominance would be more likely since microzooplankton such as ciliates show high biomass-specific grazing rates on algae (Nejstgaard et al. 2001).

The hypothesis (2) that Acartia tonsa will respond less sensitively to OA compared to a 2 -species experiments that excluded community complexity (Rossoll et al. 2012) was supported. In our study, marine copepods of $A$. tonsa seemed not to be affected by the different OA scenarios, neither directly due to decreased $\mathrm{pH}$ nor indirectly through possible food quality changes of the algae food source as indicated by abundance, development and egg production. The tendency towards higher egg production at high $\mathrm{pCO}_{2}$ level is most likely a response to the delayed phytoplankton bloom, since $A$. tonsa has no lipid reserves and thus more food was available when the adult stage was reached. Lack of direct acidification effects in Acartia species across $\mathrm{pCO}_{2}$ up to $5000 \mu \mathrm{atm}$ were shown in other experiments (Kurihara et al. 2004, Kurihara \& Ishimatsu 2008). These studies observed declining egg production rates of female adult copepods at $\mathrm{pCO}_{2}$ of $5000 \mu \mathrm{atm}$ or higher, which is far from predicted future scenarios but may be experienced in coastal habitat with upwelling of corrosive water. An adverse indirect effect might be due to $\mathrm{CO}_{2}$-driven changes in food quality, which can be transmitted to higher trophic levels and result in stunted development and reproduction. In this context a decline of total fatty acid concentrations and the concentration of specific unsaturated fatty acids in $\mathrm{CO}_{2}$ treated food algae were observed by Rossoll et al. (2012). The decline of unsaturated fatty acids at high $\mathrm{pCO}_{2}$ resulted in a significant decline in egg production rates of female A. tonsa. Since our study did not involve fatty acid measurements, we cannot exclude a change in the fatty acid profiles of algae or copepods. However, given that egg production did not decline at high $\mathrm{CO}_{2}$ level and that egg production is closely related with unsaturated fatty acid concentration (Hazzard \& Kleppel 2003), we expect no significant changes in prey and copepod fatty acid composition. The contrasting response to the study by Rossoll et al. (2012) is likely due to the simple 2-species experiment where a monoculture of Thalassiosira pseudonana was used as food source. The biochemical response of phytoplankton species to $\mathrm{CO}_{2}$ may differ greatly between species and/or taxonomic groups, and the species-specific response will further strongly dependent on other environmental variables (Joint et al. 2011).
In a more complex community the adverse $\mathrm{CO}_{2}$ effect of single specific algae might be mitigated by a major selection of several algae species, which could serve as potential food source for copepods. In a freshwater acidification study, Daphnia individuals maintained high growth rates when fed with high $\mathrm{CO}_{2}$ cultured mixed algae consisting mainly of diatoms (Urabe \& Waki 2009). This compensation effect was given even under lowered $\mathrm{P}$ and $\mathrm{N}$ contents, which was also consistent with our particulate organic measurements. In spite of the increase of $\mathrm{C}: \mathrm{N}$ ration to $\sim 9.3$ at the highest $\mathrm{CO}_{2}$ level, stoichiometric food inadequacy can be ruled out in our experiment because this value is far from being potentially limiting for copepods. The seston $\mathrm{C}: \mathrm{N}$ ratios in our experiment overlap with typical copepod C:N ratios (Walve \& Larsson 1999) and only C:N ratios clearly in excess of zooplankton biomass ratios can be limiting, because part of food $\mathrm{C}$ will be needed for respiration and not for production (Sterner \& Elser 2002). Seston C:P ratio of 115 to 130 are far beyond the P-demand of any zooplankton species and below the threshold ratio for relatively P-poor copepods. Copepods have an additional option to cope with dietary deficiencies of certain food algae: copepods can actively select between equal sized food particles based on chemical quality (DeMott 1988). In addition, most copepods can compensate nutritional inadequacy of algae by a partial or complete shift to a protozoan diet (Klein Breteler et al. 2004, Ptacnik et al. 2004).

Our hypothesis (3) was partially confirmed: most of the observed effects were driven by the difference between the 1400 and $4000 \mu \mathrm{atm}$ treatment, while differences between the 380 and $1400 \mu$ atm treatments were minor and not significant. The only significant difference was the increase of seston C:N ratios at $4000 \mu \mathrm{atm}$ during the bloom to postbloom period. However, this increase was too small to have any effect on other ecosystem components. This suggests that this coastal community is adapted to high levels of $\mathrm{CO}_{2}$, and phytoplankton has the capacity to recover immediately after exposure to $\mathrm{CO}_{2}$-induced stress. Crustaceans are in general physiologically adjusted to strong $\mathrm{pCO}_{2}$ fluctuations. Further, copepods are strong iono- and osmoregulating species and have compensatory mechanisms to respond to acid-base disruptions, which give them the ability to cope with OA (Whiteley 2011).

A caveat of our study was that the Baltic Sea community used in this experiment experienced high natural $\mathrm{pCO}_{2}$ levels that are outside the range of predicted $\mathrm{pCO}_{2}$ increase for the open ocean by the end 
of this century. Consequently, except for the extreme $\mathrm{pCO}_{2}$ treatment level, most of our treatments were in fact de-acidification treatments for the microzooplankton community - but not for A. tonsa, which originated from a stock culture. Recent studies indicate that such large $\mathrm{pCO}_{2}$ fluctuations are not unusual for productive estuarine systems, which have lower buffering capacity to seasonal variation in $\mathrm{pCO}_{2}$ (Melzner et al. 2013). This suggests that to assess the sensitivity of coastal communities, future experiments need to include $\mathrm{pCO}_{2}$ treatments that go beyond the worst scenarios projected for the open ocean (Caldeira \& Wickett 2003). Moreover, increase in hypoxia and $\mathrm{CO}_{2}$ uptake by the ocean can aggravate acidification and lead to exponential increase in $\mathrm{pCO}_{2}$, which might be outside the experienced range for coastal organisms (Feely et al. 2008, Thomsen et al. 2010). Coastal communities such as the Western Baltic Sea already experience higher $\mathrm{pCO}_{2}$ and $\mathrm{pH}$ fluctuations than open ocean plankton will encounter by the end of the century. Hence, coastal communities are not very appropriate model systems to test the sensitivity of open ocean communities to OA, as open ocean organisms are adapted to much more stable $\mathrm{pCO}_{2}$ conditions.

Although the coastal plankton community used in our experiment was highly resilient to initial OA manipulation, extreme $\mathrm{pCO}_{2}$ levels frequently observed in productive coastal systems may impose adverse effects for longer-lived and calcifying organisms that do not have the ability to adjust to rapidly acidifying water. This study indicates that the variety of biological responses, both competitive and synergistic, at the organism and population level might prevent extrapolation to the community and ecosystem level: biotic interactions might lead to a dampening (as shown here) or amplification of single species effects. In this context, manipulative acidification experiments on the community level are required for an improved comprehension of marine ecosystem responses to OA.

Acknowledgements. We thank T. Hansen and A. Ludwig for laboratory and technical assistance. This study received financial support from the European Project on Ocean Acidification (EPOCA, FP7, 211384) and the Marie Curie IRG grant 276917.

\section{LITERATURE CITED}

Beaufort L, Probert I, de Garidel-Thoron T, Bendif EM and others (2011) Sensitivity of coccolithophores to carbonate chemistry and ocean acidification. Nature 476:80-83

Bellerby RGJ, Schulz KG, Riebesell U, Neill C and others (2008) Marine ecosystem community carbon and nutrient uptake stoichiometry under varying ocean acidification during the PeECE III experiment. Biogeosciences 5: 1517-1527

> Berge T, Daugbjerg N, Andersen BB, Hansen PJ (2010) Effect of lowered $\mathrm{pH}$ on marine phytoplankton growth rates. Mar Ecol Prog Ser 416:79-91

> Caldeira K, Wickett ME (2003) Anthropogenic carbon and ocean pH. Nature 425:365-365

> Cao L, Caldeira K (2008) Atmospheric $\mathrm{CO}_{2}$ stabilization and ocean acidification. Geophys Res Lett 35:L19609, doi: 10.1029/2008GL035072

> Cooley SR, Kite-Powell HL, Doney SC (2009) Ocean acidification's potential to alter global marine ecosystem services. Oceanography 22:172-181

$>$ de Nooijer LJ, Toyofuku T, Kitazato H (2009) Foraminifera promote calcification by elevating their intracellular $\mathrm{pH}$. Proc Natl Acad Sci USA 106:15374-15378

> DeMott W (1988) Discrimination between algae and artificial particles by freshwater and marine copepods. Limnol Oceanogr 33:397-408

Dickson A, Afghan J, Anderson G (2003) Reference materials for oceanic $\mathrm{CO}_{2}$ analysis: A method for the certification of total alkalinity. Mar Chem 80:185-197

Doney SC, Fabry VJ, Feely RA, Kleypas JA (2009) Ocean acidification: the other $\mathrm{CO}_{2}$ problem. Annu Rev Mar Sci 1:169-192

Engel A, Schulz KG, Riebesell U, Bellerby R, Delille B, Schartau M (2008) Effects of $\mathrm{CO}_{2}$ on particle size distribution and phytoplankton abundance during a mesocosm bloom experiment (PeECE II). Biogeosciences 5: 509-521

Fabry VJ, Seibel BA, Feely RA, Orr JC (2008) Impacts of ocean acidification on marine fauna and ecosystem processes. ICES J Mar Sci 65:414-432

Feely RA, Sabine CL, Hernandez-Ayon JM, Ianson D, Hales B (2008) Evidence for upwelling of corrosive 'acidified' water onto the continental shelf. Science 320:1490-1492

$>$ Fu F, Warner M, Zhang Y, Feng Y, Hutchins D (2007) Effects of increased temperature and $\mathrm{CO}_{2}$ on photosynthesis, growth and elemental ratios of marine Synechococcus and Prochlorococcus (Cyanobacteria). J Phycol 43: 485-496

> Gosling SN, Warren R, Arnell NW, Good P and others (2011) A review of recent developments in climate change science. Part II: The global-scale impacts of climate change. Prog Phys Geogr 35:443-464

Grasshoff K, Ehrhardt M, Kremling K (eds) (1983) Methods of seawater analysis. Verlag Chemie, Basel

Hazzard SE, Kleppel GS (2003) Egg production of the copepod Acartia tonsa in Florida Bay: role of fatty acids in the nutritional composition of the food environment. Mar Ecol Prog Ser 252:199-206

> Hinga KR (2002) Effects of pH on coastal marine phytoplankton. Mar Ecol Prog Ser 238:281-300

> Holste L, Peck MA (2006) The effects of temperature and salinity on egg production and hatching success of Baltic Acartia tonsa (Copepoda: Calanoida): a laboratory investigation. Mar Biol 148:1061-1070

IPCC (2007) Climate change 2007: The physical science basis. Contribution of Working Group I to the Fourth Assessment Report of the Intergovernmental Panel on Climate Change. Cambridge University Press, Cambridge and New York, NY

Joint I, Doney SC, Karl DM (2011) Will ocean acidification affect marine microbes? ISME J 5:1-7 
Kim JM, Lee K, Shin K, Kang JH and others (2006) The effect of seawater $\mathrm{CO}_{2}$ concentration on growth of a natural phytoplankton assemblage in a controlled mesocosm experiment. Limnol Oceanogr 51:1629-1636

Klein Breteler WCM, Koski K, Rampen S (2004) Role of essential lipids in copepod nutrition: no evidence for trophic upgrading of food quality by a marine ciliate. Mar Ecol Prog Ser 274:199-208

Kurihara H, Ishimatsu A (2008) Effects of high $\mathrm{CO}_{2}$ seawater on the copepod (Acartia tsuensis) through all life stages and subsequent generations. Mar Pollut Bull 56:1086-1090

Kurihara H, Shimode S, Shirayama Y (2004) Sub-lethal effects of elevated concentration of $\mathrm{CO}_{2}$ on planktonic copepods and sea urchins. J Oceanogr 60:743-750

Lohbeck KT, Riebesell U, Reusch TBH (2012) Adaptive evolution of a key phytoplankton species to ocean acidification. Nat Geosci 5:346-351

Melzner F, Thomsen J, Koeve W, Oschlies A and others (2013) Future ocean acidification will be amplified by hypoxia in coastal habitats. Mar Biol doi:10.1007/ s00227012-1954-1

Müller MN, Schulz KG, Riebesell U (2010) Effects of longterm high $\mathrm{CO}_{2}$ exposure on two species of coccolithophores. Biogeosciences 7:1109-1116

> Nejstgaard JC, Hygum BH, Naustvoll LJ, Båmstedt U (2001) Zooplankton growth, diet and reproductive success compared in simultaneous diatom- and flagellate-microzooplankton-dominated plankton blooms. Mar Ecol Prog Ser 221:77-91

> Nielsen LT, Jakobsen HH, Hansen PJ (2010) High resilience of two coastal plankton communities to twenty-first century seawater acidification: evidence from microcosm studies. Mar Biol Res 6:542-555

Paasche E (2001) A review of the coccolithophorid Emiliania huxleyi (Prymnesiophyceae), with particular reference to growth, coccolith formation, and calcificationphotosynthesis interactions. Phycologia 40:503-529

Ptacnik R, Sommer U, Hansen T, Martens V (2004) Effects of

Editorial responsibility: Graham Savidge,

Portaferry, UK microzooplankton and mixotrophy in an experimental planktonic food web. Limnol Oceanogr 49:1435-1445

Riebesell U, Bellerby RGJ, Grossart HP, Thingstad F (2008) Mesocosm $\mathrm{CO}_{2}$ perturbation studies: from organism to community level. Biogeosciences 5:1157-1164

Rossoll D, Bermúdez R, Hauss H, Schulz KG, Riebesell U, Sommer U, Winder M (2012) Ocean acidification-induced food quality deterioration constrains trophic transfer. PLoS ONE 7:e34737

Sterner RW, Elser JJ (2002) Ecological stoichiometry: the biology of elements from molecules to the biosphere. Princeton University Press, Princeton, NJ

Strickland JDH, Parsons TR (1968) A practical handbook of seawater analysis. Queen's Printer, Ottawa

> Thomsen J, Gutowska MA, Saphörster J, Heinemann A and others (2010) Calcifying invertebrates succeed in a naturally $\mathrm{CO}_{2}$-rich coastal habitat but are threatened by high levels of future acidification. Biogeosciences 7:3879-3891

Urabe J, Waki N (2009) Mitigation of adverse effects of rising $\mathrm{CO}_{2}$ on a planktonic herbivore by mixed algal diets. Glob Change Biol 15:523-531

> Urabe J, Togari J, Elser JJ (2003) Stoichiometric impacts of increased carbon dioxide on a planktonic herbivore. Glob Change Biol 9:818-825

Utermöhl H (1958) Zur Vervollkommnung der quantitativen Phytoplankton-Methodik. Verh Int Ver Theor Angew Limnol 9:263-272

> Van de Waal DB, Verspagen JMH, Finke JF, Vournazou V and others (2011) Reversal in competitive dominance of a toxic versus non-toxic cyanobacterium in response to rising $\mathrm{CO}_{2}$. ISME $\mathrm{J}$ 5:1438-1450

> Walve J, Larsson U (1999) Carbon, nitrogen and phosphorus stoichiometry of crustacean zooplankton in the Baltic Sea: implications for nutrient recycling. J Plankton Res 21:2309-2321

> Whiteley NM (2011) Physiological and ecological responses of crustaceans to ocean acidification. Mar Ecol Prog Ser 430:257-271

Submitted: August 21, 2012; Accepted: March 26, 2013

Proofs received from author(s): June 28, 2013 